\title{
Performance of Ultrafiltration-Ozone Combined System for Produced Water Treatment
}

\author{
Nita Aryanti1,2*, Tutuk Djoko Kusworo',2, Wiharyanto Oktiawan³, Dyah Hesti Wardhani ${ }^{1}$ \\ 1 Department of Chemical Engineering, Faculty of Engineering, Diponegoro University, \\ Kampus Undip Tembalang, 50275 Semarang, Indonesia \\ 2 Membrane Research Centre (MeR-C), Diponegoro University, Kampus Undip Tembalang, 50275 Semarang, Indonesia \\ ${ }^{3}$ Department of Environmental Engineering, Faculty of Engineering, Diponegoro University, \\ Kampus Undip Tembalang, 50275 Semarang, Indonesia \\ *Corresponding author, e-mail: nita.aryanti@che.undip.ac.id
}

Received: 24 November 2018, Accepted: 25 February 2019, Published online: 03 April 2019

\begin{abstract}
Oil exploration waste, also called produced water, contains hazardous pollutants, such as benzene; benzene, toluene, and xylene (BTX); naphthalene, phenanthrene, and dibenzothiophene (NDP); polyaromatic hydrocarbons (PAHs); and phenol. Produced water is characterized by high chemical oxygen demand (COD) and oil content, which exceed the standard limits of regulation. In this study, the combination of ultrafiltration (UF) and ozone pre-treatment and post-treatment were applied for treatment of produced water to minimize its environmental impact. Produced water and membrane were characterized, and their ultrafiltration performance for removal of oil content, benzene, toluene, xylene, and COD. Two commercial Polyethersulfone membranes, with molecular-weight cutoff values of 10 and $20 \mathrm{kDa}$, were used. The membrane flux profile illustrated that ozone pre-treatment had higher normalized flux than UF only. Separation performance was evaluated based on flux profile and removal of COD, oil and grease content, toluene, and xylene. Significant finding was found where the combination of UF with ozone pre-treatment and post-treatment could significantly eliminate COD, oil content, toluene, and xylene. The rejection of these components was found higher than conventional process, which was in the range of $80 \%$ to $99 \%$. In addition, almost oil and grease can be removed by using this combined system. Permeate quality of this system confirmed the acceptable level as water discharge.
\end{abstract}

Keywords

ultrafiltration, ozone, produced water, benzene, toluene, xylene

\section{Introduction}

Oil explorations are the primary source of energy, and their corresponding activities generate a large volume of oilfield wastewater, also referred as produced water. For each barrel of oil, three barrels of produced water are generated [1]. In general, produced water is reused to enhance oil recovery or treated prior to discharge into the environment. Produced water comprises various organic and inorganic substances, which are potentially characterized as hazardous and toxic wastes. Produced water compound is categorized as organic substance, inorganic substance, and radionucleotide. Moreover, produced water contains some important compounds, such as dissolved and dispersed oil compounds, dissolved formation minerals, production chemical compounds, production solids, and dissolved gases [2]. Oils consist of monocyclic aromatic hydrocarbons such as benzene, toluene, ethylbenzene, and xylene (BTEX), polyaromatic hydrocarbons (PAH), and related heterocyclic aromatic compounds [3]. BTEX and phenols are dissolved in water. Residual chemicals, such as corrosion and scale inhibitors, emulsion breakers, and biocides, are also present in produced water [4].

Compounds in produced water are toxic and adversely affect the environment. Bakke et al. [5] published a review of the environmental impact of produced water and oil drilling in the offshore petroleum industry. Alkylphenols, naphthenic acids, and PAHs from produced water may disrupt reproductive functions and affect several chemicals, biochemical, and genetic biomarkers. As a consequence of the lethal effects of produced water contaminants, many countries have implemented a stringent regulatory 
standard for discharging produced water to alleviate their adverse environmental impacts. Produced water quality can be represented as oil content or concentration and chemical oxygen demand (COD). The concentrations of oil and COD in produced water are relatively high, reaching 565 and $1220 \mathrm{mg} / \mathrm{L}$, respectively [1]. The government of the Republic of Indonesia through Regulation of the Minister of State for Environment No. 19 set standard limits for wastewater for oil and gas activities in 2010. The permitted oil concentration and COD are within 20-50 and $200 \mathrm{mg} / \mathrm{L}$, respectively. Hence, treatment of produced water is a responsibility for oil and gas explorations.

Membrane technology has been applied to treat produced water and reviewed comprehensively [6, 7]. Ultrafiltration membrane is also an appropriate method for produced water treatment. Ultrafiltration (UF) is a low-pressure driven membrane filtration process operating at 2-10 bar [8]. The pore size of an UF membrane ranges from 0.001 $\mu \mathrm{m}$ to $0.1 \mu \mathrm{m}$; as such, the membrane rejects compounds with molecular weight of 1000 to 100.000 Da [9].

Several researchers have examined the use of UF membranes for handling produced water [10-14]. The previous study showed that UF treatment was able to reject $87.82 \%$ of COD, $98.7 \%$ of oil, $90.5 \%$ of Total Organic Compound (TOC) from produced water by using $20 \mathrm{kDa}$ UF membrane [12]. The treatment of oil-field produced water using UF ceramic membrane also presented a good removal of oil content with $99.15 \%$ of oil rejection [11].

However, studies on produced water treatment only investigated method performance through determination of general effluent parameters, such as COD, BOD, total dissolved solids, total suspended solids, oil content, and total organic carbon and analysis of anions and cations. Several studies have evaluated specific BTX content in produced water [15-17]. However, to the best of our knowledge, limited works have examined the performance of UF in BTX removal. The present study mainly aims to investigate the performance of ultrafiltration in treating produced water, specifically in filtering BTX pollutants. In detail, Polyethersulfone (PES) was selected as membrane material for ultrafiltration due to its hydrophilic property. To enhance the ultrafiltration performance, this research combined ultrafiltration and ozone pre-treatment and post-treatment for removal of produced water compounds. Ozone was selected because it can break up large organic molecules. Ozone can break complex molecular organic compounds in crude oil, which is a component of produced water [18-19]. Ziabari et al. [20] studied the removal of hydrocarbons from aqueous solution by ozonation. In addition, Zha et al. [21] reported that ozone could oxidize compounds having a large molecular weight to generate smaller compounds. Ozone can also reduce fouling associated with microfiltration and ultrafiltration [22-25]. Hence, we confirm the novelty of this research by implementing the combination of ultrafiltration and ozone to improve ultrafiltration performance for produced water treatment. The improvement was achieved not only in the term of permeate quality but also reduction of membrane fouling. Results provide novel significant findings in this research area.

\section{Materials and Method}

\subsection{Membrane characterization}

Two available commercial membranes made of PES (NADIR Filtration, Germany) were used to filter produced water. Membranes with molecular-weight cut-off of 10 and $20 \mathrm{kDa}$ and were labelled as PES 1 and PES 2, respectively. Specific functional groups were identified using Fourier transform infrared spectroscopy (Shimadzu IR Prestige-21). Specific functional groups were examined based on their wavelength as a function of absorbance (Fig. 1).

Similar peaks at 1577.77 and $1485.19 \mathrm{~cm}^{-1}$ are characteristics of PES membrane. Peaks at 1485.19 and $1577.77 \mathrm{~cm}^{-1}$

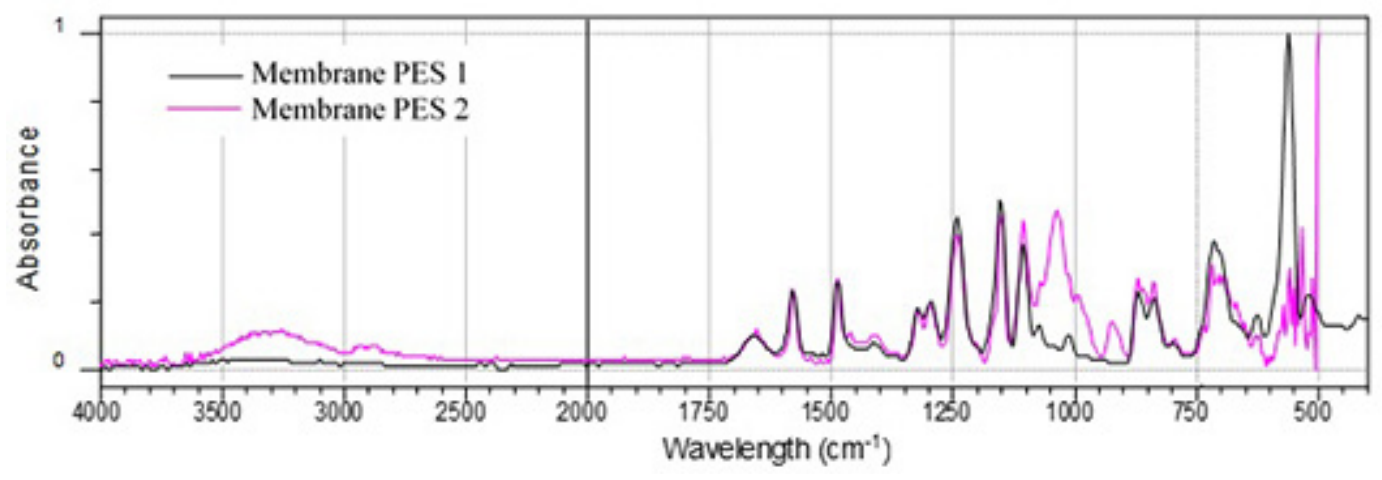

Fig. 1 FTIR results of PES 1 and PES 2 membranes 
indicate the presence of aromatic components $(\mathrm{C}=\mathrm{C}$ stretching) in benzene, and peaks at 1240.23 and $1242.16 \mathrm{~cm}^{-1}$ represent ether aromatic compounds [26-27]. In addition, peaks at 1151.5 and $1105.21 \mathrm{~cm}^{-1}$ exhibit $\mathrm{SO}_{2}$ symmetrical stretching and are assigned to a sulfuric component. Peaks at 1656 and $1321 \mathrm{~cm}^{-1}$ are predicted as preservative PVP (poly-N-vinyl-2-pyrrolidone) because it is an additive polymer used for pore formation on PES and polysulfone membrane [27]. Moreover, a specific peak at $3500-3000 \mathrm{~cm}^{-1}$ is assigned to PES 2 membrane and indicates the existence of $\mathrm{OH}$ stretching radical. The PES 2 membrane was predicted to be more hydrophilic than the PES 1 membrane. To confirm this finding, the contact angle of the membrane was measured by using Optical Contact Angle Meter (DataPhysics, OCA 15LJ). The contact angle of the PES 1 and PES 2 membrane were $70.7^{\circ}$ and $50.1^{\circ}$, respectively.

Table 1 summarizes the properties of UF membrane in relation to its pore size and water flux. Table 1 shows that the pure water flux of the PES 2 membrane was higher than that of the PES 1 membrane. The pure water flux was mainly determined by membrane pore size and its surface hydrophilicity [28]. Given that the PES 2 membrane possessed a large pore size, it exhibited higher pure water flux. Membrane surface morphology was analyzed by scanning electron microscopy (FEI, Type Inspect-S50, Japan) at a specific magnification.

\subsection{Ultrafiltration}

Ultrafiltration experiments were conducted in a homemade laboratory-scale test cell. The apparatus consisted of a $500 \mathrm{~mL}$ feed tank, a pump (Kemflow, with nominal flow rate of $1.0 \mathrm{~L} / \mathrm{min}$, maximum pump output of 7.58 bar, maximum inlet pressure of 4.14 bar), a pressure gauge (JAKO, maximum pressure of 10.34 bar), and a stainless steel membrane cell. The pressure and flow rate were controlled using feed valve (Needle Valve, 1/4" FNPT x 1/4" FNPT, maximum pressure of 5000 psi, materials SS 316). Fig. 2 shows the schematic of the ultrafiltration cell.

All filtration runs were carried out at room temperature $\left(25 \pm 2{ }^{\circ} \mathrm{C}\right)$. The membrane was compacted by filtering water through the membrane at a pressure of 2 bar for 0.5 h. For each experimental run, a new circular membrane sheet with an area of $13.85 \mathrm{~cm}^{2}$ was used for measurement of

Table 1 Properties of UF membranes used in this work

\begin{tabular}{lcc}
\hline Membrane & MWCO $(\mathrm{Da})$ & Pure Water Flux $\left(\mathrm{L} / \mathrm{m}^{2} . \mathrm{hr}\right)$ \\
\hline PES-1 & 10.000 & 11.25 \\
PES-2 & 20.000 & 94.27 \\
\hline
\end{tabular}

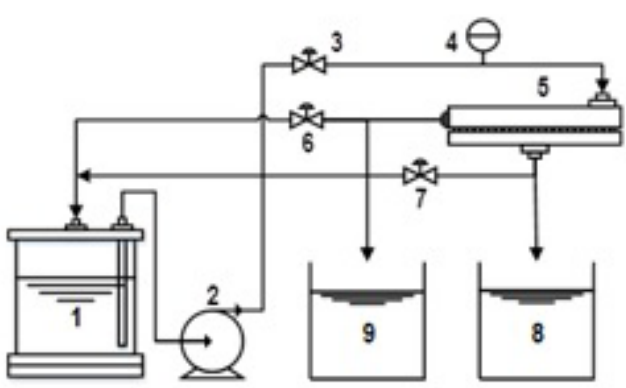

1. Feed Tank

2. Feed Pump

3. Feed Valve

4. Pressure Gauge

5. UF Membrane Module
6. Retentate Recycle Valve

7. Permeate Recycle Valve

8. Permeate Tank

9. Retentate Tank
Fig. 2 Schematic of the ultrafiltration cell

initial water flux $\left(J_{0}\right)$. Initial water flux $\left(J_{0}\right)$ was determined by filtering pure water using a new clean membrane, then measuring the volume of water permeate collected at a specific recording time. Filtrations were carried out using total recycle mode, where both permeate, and retentate were recycled to the feed tank, to maintain the same concentration. Permeate flux $(J)$ was determined by analytically weighting permeate collected at every $5 \mathrm{~min}$ intervals for $60 \mathrm{~min}$. Membrane or permeate fluxes $(J)$ were calculated by dividing the volume of permeate $(Q)$ by the effective membrane area $(A)$ and the sampling time $(t)$, as defined in Eq. (1):

$J=\frac{1}{A \cdot t} Q$

where:

$J$ : flux $\left(\mathrm{L} / \mathrm{m}^{2} \mathrm{~h}\right), Q$ : volume $(\mathrm{L}), A$ : membrane area $\left(\mathrm{m}^{2}\right)$, and $t$ : time interval (h).

The ability of the membrane for removing specific pollutants from produced water was determined by $\%$ rejection $(\% R)$. Membrane rejection was calculated by dividing the difference between the concentration of a specific pollutant in the feed $\left(C_{f}\right)$ with the concentration of specific pollutants in permeate $\left(C_{p}\right)$, as expressed in Eq. (2).

$\% R=\left(1-\frac{C_{p}}{C_{f}}\right) \times 100 \%$

In this research, the term rejection and permeate and feed concentrations refers to rejection and concentrations of COD, total oil content, toluene, and xylene.

\subsection{Ozonation}

Ozonation pre-treatment and post-treatment were conducted by Ozonizer, a generator (Krisbow) and flow meter. In the pre-treatment process, ozone was purged into the 
produced water feed. For the post-treatment, ozone was added into the permeate. Ozone concentration was tested using HI38054 Ozone Test kit. The ozone flow rate was set as $2 \mathrm{~L} / \mathrm{min}$, the contact time was $5 \mathrm{~min}$, and the corresponding ozone concentration was $0.3 \mathrm{mg} / \mathrm{L}$.

\subsection{Produced Water Quality Analysis}

Produced water was collected from offshore facilities in Cepu region, Central Java, Indonesia. Water quality was assessed using the produced water in the feed and permeate. The COD in the feed and permeate samples were determined by Test Tube Heater-COD Reactor (HANA HI 839800) for 2 hours at temperature of $150^{\circ} \mathrm{C}$. Analysis of the contents of oil, BTX was conducted through gas chromatography. Ammonia value was obtained using UV-Vis spectrophotometry (Perkin Elmer Lambda 20). The spectrophotometric analysis was performed based on the methods explained by Zadorojny et al. [29]. The similar method was adopted by Indonesian standard analysis (SNI 06-6989.30-2005). Table 2 shows the characteristics of produced water.

According to Table 2, the mean levels of benzene, toluene, and xylene in the produced water sample were below $0.8,2.62$, and $3.11 \mathrm{mg} / \mathrm{L}$, respectively. For comparison, produced water which was collected from the Bonsucesso treatment plant, State of Sergipe, Brazil had average concentrations of 1397,1263 , and $312 \mu \mathrm{g} / \mathrm{L}$ for benzene, toluene, and xylene, respectively [16]. Similar results were also found in an oilfield wastewater platform in the Gulf of Mexico. Examination of oilfield wastewater in that area indicated that the concentrations of benzene, toluene, and xylene were $0.8-4.6,1.0-3.5$, and $0.2-0.7 \mathrm{mg} / \mathrm{L}$, respectively [17]. In the Campos Basin, State of Rio de Janeiro, Brazil, the levels of benzene, toluene, and xylene were 283-1855, 87.04-2224, and 67.35-5969 $\mathrm{mol} / \mathrm{L}$, respectively [15].

Table 2 Characteristics of produced water used in this study

\begin{tabular}{lc}
\hline Parameter & Value \\
\hline COD & $1872 \mathrm{mg} / \mathrm{L}$ \\
Oil and grease content & $931.01 \mathrm{mg} / \mathrm{L}$ \\
Benzene & $<0.8 \mathrm{mg} / \mathrm{L}$ \\
Toluene & $2.62 \mathrm{mg} / \mathrm{L}$ \\
Xylene & $3.11 \mathrm{mg} / \mathrm{L}$ \\
Phenol & $<0.03 \mathrm{mg} / \mathrm{L}$ \\
Ammonia & $0.22 \mathrm{mg} / \mathrm{L}$ \\
$\mathrm{pH}$ & 8 \\
\hline
\end{tabular}

\section{Results and Discussions}

\subsection{Membrane Flux Behaviour}

Normalization of flux profiles $\left(J / J_{0}\right)$ as a function of time is presented in Fig. 3. In general, the flux showed a declining trend during ultrafiltration. The reduction of membrane flux is a characteristic of membrane fouling, which can be generated by an increase in membrane resistance due to pore blocking, concentration polarization, and cake formation [23]. Fouling can be related to the accumulation of a substance (called foulant) on the membrane surface or inside the membrane pores. At the beginning of ultrafiltration, no foulant deposit was found on the membrane surface. As time increased, foulants accumulated on the membrane surface and generated a cake layer, leading to decreased flux value and normalized fluxes.

In the ultrafiltration treatment of produced water, its components, such as oil and other organic compounds, are significant sources of fouling. Ashaghi et al. [30] and Maguire-Boyle and Barron [31] proposed that fouling during filtration of produced water could be due to biofouling, scaling, organic fouling, and colloidal fouling. Fouling could also be attributed to microbial contaminants (biofouling), salt precipitation resulting in scaling, organic fouling due to pore plugging or pore coating by hydrocarbon compounds, and clay and silica accumulation on the membrane surface (colloidal fouling). However, flux reduction was relatively steady along with time because of the compression of the cake layer and its constant thickness.

The flux decline of the PES 2 membrane was more pronounced than that of the PES 1 membrane. The flux decline (final flux compared with the initial flux) values of PES 2 and PES 1 membranes were found to be $8.7 \%$ and $2.5 \%$,

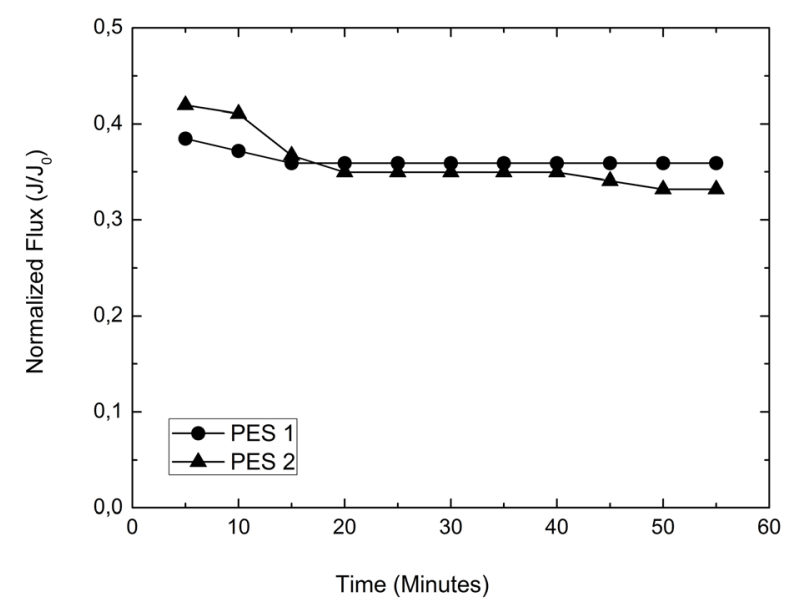

Fig. 3 Performance of membrane normalized fluxes as a function of time in treatment of produced water by using membranes with different pore sizes $(\mathrm{TMP}=1 \mathrm{bar})$ 
respectively. The flux decline can be explained by membrane fouling caused by pore blocking or membrane adsorption due to contaminants in the produced water. The pore size of the PES 1 membrane was slightly smaller than that of the PES 2 membrane. Contaminants with size bigger than the membrane pores have a tendency to form a cake layer on the membrane surface. By contrast, contaminants with size smaller than the membrane pores are likely to induce membrane pore blocking or adsorption. In the PES 2 membrane, contaminants most likely close the membrane pores strongly and accumulated on the membrane surface [32].

Two levels of trans-membrane pressure (TMP) were applied to study its effect on membrane behaviour in produced water treatment (Fig. 4).

The initial normalized flux was high at high TMP but decreased at the end of the process. The flux decrease at TMP of 2 bar (59\%) was higher than that at 1 bar (2.5\%). As a general rule, the increase in TMP in ultrafiltration of oil exerts negative and positive influences on the permeate flux [33]. At high TMP, more oil droplets and solutes passed quickly through the membrane pores. However, more oil droplets contributed to oil droplet accumulation both on the membrane surface and in the pores. The accumulation of oil droplets led to the formation of a cake layer on the membrane surface. It is predicted that initially a gel layer is formed due to some solutes congeal on the membrane surface. A steady state of flux is obtained with assumption that the concentration does not increase. However, with the increase of pressure, the gel layer is transformed into cake layer. In cake layer, the fouling increases continuously and result in complete blocking with no flux. The use of high TMP also resulted in the

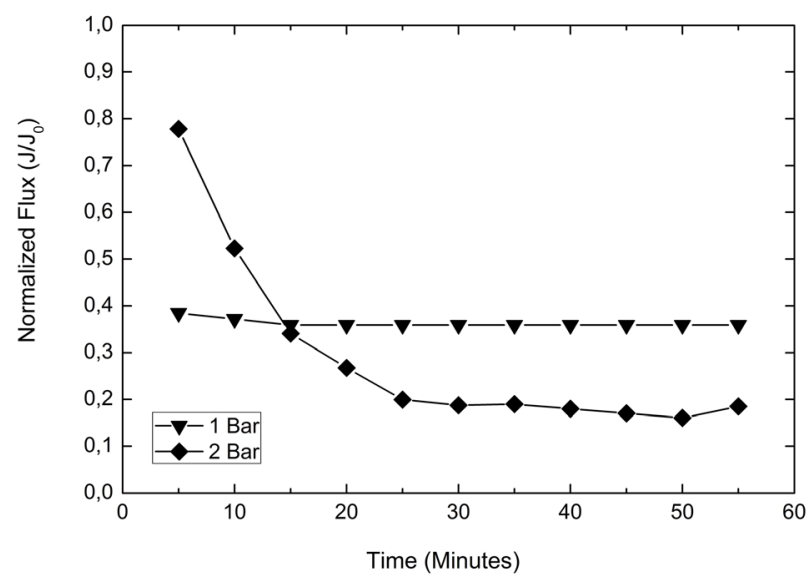

Fig. 4 Behavior of membrane normalized fluxes as a function of time in treatment of produced water under different trans membrane pressure levels (membrane : PES 1) formation of a cake layer covering the membrane pores, thereby inducing membrane fouling [34].

Fig. 5 represents the effect of ozonation pre-treatment on ultrafiltration behaviour.

The normalized flux of the PES 1 membrane with ozone pre-treatment was higher than without ozone pre-treatment, but the flux decrease after ozone pre-treatment remained high. The flux decline of the membrane with ozone pre-treatment was about $18.5 \%$, whereas the flux decrease of the membrane without ozone pre-treatment was only about $2.5 \%$. Ozone can oxidize the majority of organic compounds (about $35 \%$ ) in produced water into smaller intermediate products, which are then decomposed into $\mathrm{CO}_{2}$ and $\mathrm{H}_{2} \mathrm{O}$ [21]. Ozonation of produced water could also generate new compounds, such as acids, amines, and aldehyde, which influence the fouling rate of membranes during filtration. Fig. 6 reveals that ozone pre-treatment can diminish membrane fouling, as indicated by the superior normalized flux profile of the membrane subjected to UF with ozone pre-treatment over that subjected to UF only. The flux decline was significant in the first stage of filtration but became steady thereafter. Pre-ozonation can also reduce dissolved organic carbon by mineralization of small organic molecules. The breaking of large molecules was found to be the dominant principle for fouling reduction [22]. This finding was supported by the images of the SEM membrane illustrated in Fig. 6.

Fig. 6 confirms the clean surface of the new membrane (Fig. 6(a)) without any substances on its top. By contrast, Fig. 6(b) shows some foulants deposited on the membrane surface when filtering produced water without pre-treatment. The foulant deposits formed a cake layer, with some small particles found above the cake layer. The foulants

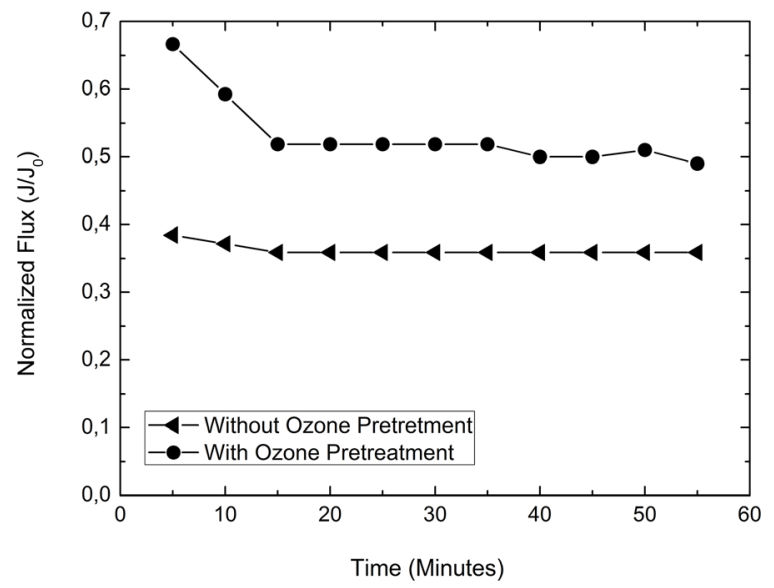

Fig. 5 Effect of ozonation pre-treatment on membrane normalized fluxes as a function of time for ultrafiltration of produced water (membrane: PES 1, TMP = 1 bar) 

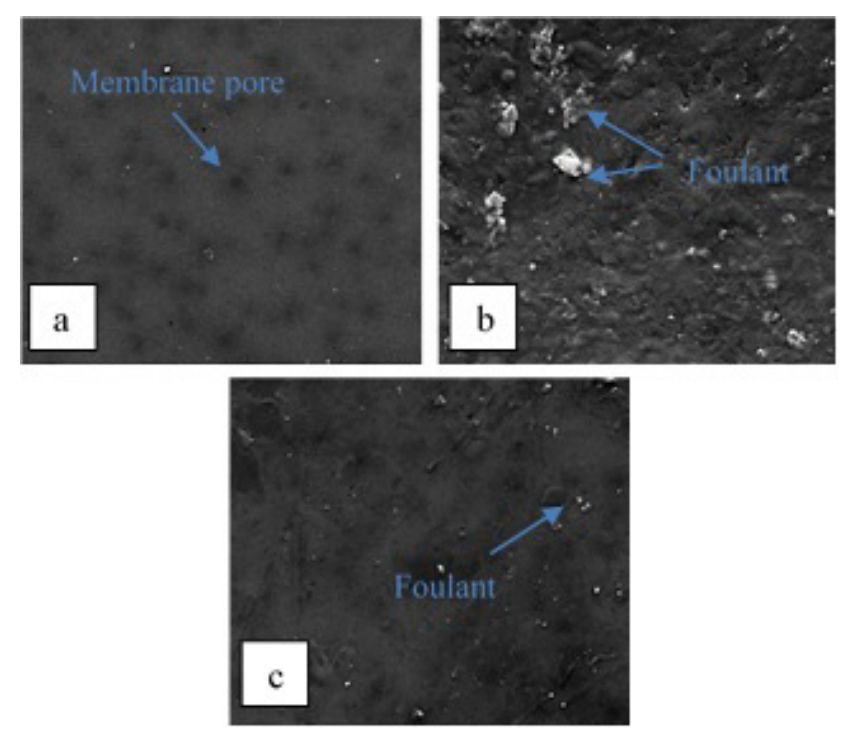

Fig. 6 SEM result of PES membranes (magnification of 20,000 $\times$ : (a) clean membrane (before filtration), (b) membrane after filtration without ozone pre-treatment, and (c) membrane after filtration with ozone pre-treatment. (membrane PES $1, \mathrm{TMP}=1$ bar)

were almost certainly suspended solids and large-molecular-weight compounds, such as xylene, toluene, benzene, and phenol in the produced water; as such, the foulants blocked the membrane surface and then formed a cake layer. At a certain period, foulant particles accumulated and generated a thick cake layer, thereby promoting the deposition of the foulant on the cake surface. During the filtration of produced water feed with ozone pre-treatment (Fig. 6(c)), the membrane surface showed a better appearance. Some foulant deposits were observed, but their size was smaller than that in the deposits shown in Fig. 6(b). Organic substances present in produced water

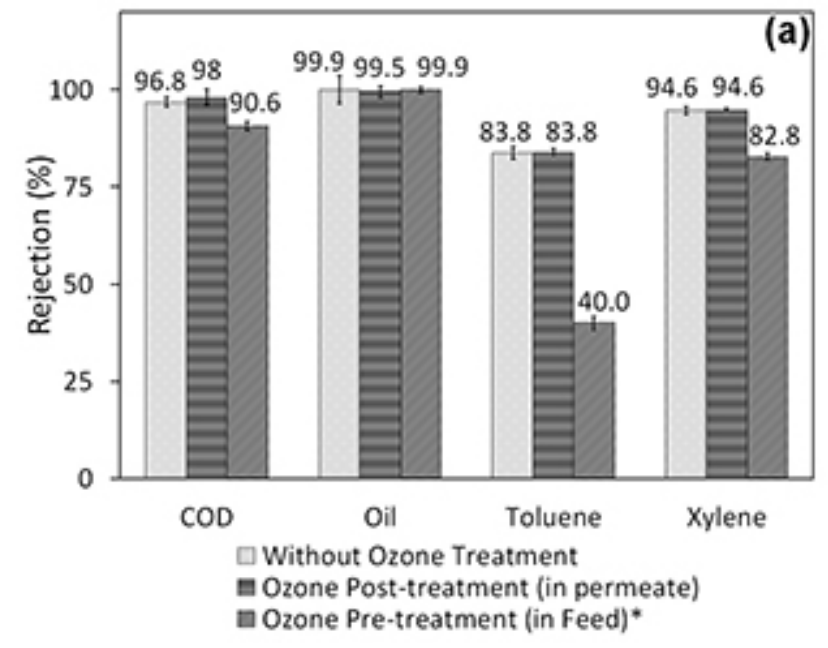

are responsible for membrane fouling. Song et al. [35] also described that membrane fouling was produced by organic substances with a high molecular weight. Ozone may also oxidize organic compounds in produced water and effectively decrease the risk of fouling of the membrane. A similar result was also found by You et al. [25], who confirmed that the $\mathrm{C}=\mathrm{H}$ bonds in the aromatic rings could be eliminated by ozone and more $\mathrm{C}-\mathrm{H}$ and $\mathrm{C}-\mathrm{H}$ bonds could be produced in the alkanes. Moreover, ozone can destroy aromatic rings to form few alkanes with a linear chain.

\subsection{Membrane Rejection}

In the ultrafiltration membrane, membrane selectivity is determined by membrane rejection. The ability of the PES membrane to selectively resist COD, oil, toluene and xylene in the produced water is shown in Fig. 7.

The ultrafiltration membrane showed significantly high rejection rates for $\mathrm{COD}$, oil and grease, toluene, and xylene under various conditions, except for toluene during ozone pre-treatment. The low value of toluene rejection did not indicate its high concentration in the permeate because ozone pre-treatment could significantly reduce the toluene concentration. The rejection of the PES 1 membrane for COD and oil and grease concentration was slightly greater than that of the PES 2 membrane, which has bigger pore size. In membranes with a large pore size, oil that accumulated on the membrane surface will possibly permeate through large pores, resulting in slightly higher oil concentration in the permeate. Rejection or removal efficiency of this system to decrease oil and grease was considerably high (in the range of 98-99.9\%) showing that almost all oil was removed. Physical treatment such as EPCON

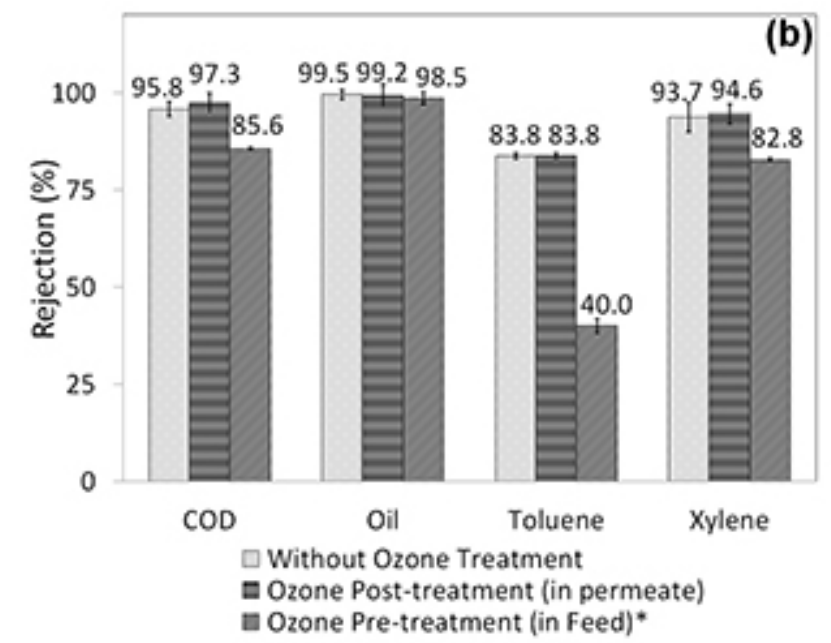

Fig. 7 Rejection of COD, oil, toluene, and xylene under various conditions (TMP = 1 bar): (a) PES 1 and (b) PES 2 $*\left(\mathrm{C}_{\mathrm{f}}\right.$ Toluene $=\mathrm{C}$ Toluene after feed ozonation $\left.=0.10 \mathrm{mg} / \mathrm{L}\right)$. 
compact floatation unit reduced $50-70 \%$ dispersed oil [36]. Applying a copolymer could absorb up to $85 \%$ of oil in produced water [37]. On the other hand, utilizing biological treatment such as rotating disk, aerated biological filter was only able to reduce oil and grease to $74 \%$ [38].

Oil can be categorized as an organic compound; hence, the value of COD in the permeate was high, corresponding to low COD rejection. Implementation of this system is able to reduce the COD in the range of $85.6-98 \%$. This value of reduction is considerably high since the COD reduction by applying another method was low. Using electrochemical oxidation only removed up to $57 \%$ of initial COD concentration [39]. The sequence batch reactor (SBR), with acclimated sewage sludge, had COD removal efficiencies varied from $30 \%$ to $50 \%$ [40] and applying microwave (MW)-assisted Catalytic Wet Air Oxidation (CWAO) in produced water treatment showed more than $90 \%$ of COD was removed [41]. This combined system of ultrafiltration-ozone was also confirmed superior to the immobilization of microorganism for produced water treatment that was only removed $90 \%$ of initial COD at COD concentration of $2600 \mathrm{mg} / \mathrm{L}$ [42].

Table 3 presents the characteristics of ultrafiltration permeate and the standard regulation of on-shore produced water in Indonesia. According to the table, permeates both with UF only and ozone combined-UF are in the range of acceptable level for water discharge. The result is significant since this method was able to reduce the oil and grease to a very low level $(<0.03-8.18 \mathrm{mg} / \mathrm{L})$ compared to the existing method. It is reported that the conventional method of produced water treatment reduced the oil and grease concentrations to $30-40 \mathrm{mg} / \mathrm{L}$ [37]. In addition, almost all of benzene, toluene, and xylene were removed during the ultrafiltration of produced water under various conditions.
This result is superior compared to other methods of produced water treatment. It was reported that neutralized amine "tailored" zeolites were applied in produced water treatment, and only able to remove around 70 and $85 \%$ of BTEX from saline produced water [38]. In addition, this ultrafiltration-ozone combined system achieved similar result with the commercially available method such as Macro-porous Polymer Extraction (MPPE) technology, which the MPPE achieved $99 \%$ removal of BTEX [38].

Produced water contains crude oil, which is a mixture of hydrocarbons, such as naphthalene, phenanthrene, dibenzothiophene, polyaromatic hydrocarbons (PAHs), and phenols. These hydrocarbons could not be dissolved but are dispersed in produced water. In this research, ultrafiltration membranes with molecular-weight cut-off (MWCO) values of 10.000 and 20.000 Da and pore sizes of 0.01 and $0.02 \mu \mathrm{m}$ were used. The membranes rejected compounds with molecular weight within 10.000 and 20.000 Daltons. Produced water comprises organic compounds, such as benzene, toluene, and xylene (BTX), which have lower molecular weight than the molecular weight cut-off. When applying the "membrane-sieving principle", the BTX components should pass through the membrane pores. However, the results showed high rejection rates for toluene and xylene. BTX exists as dispersed oil and has size larger than that of the membrane pores; hence, BTX was rejected by the ultrafiltration membrane.

Ozonation pre-treatment significantly reduced the concentrations of toluene and xylene and COD. This method is accurate because ozone can degrade macromolecular matter into small organic matter [21] and change the composition and hydrophilicity of organic matter [35]. Šilhárová et al. [18] provided evidence that ozone treatment led to a low concentration of organic petroleum compound (BTEX).

Table 3 Comparison of the quality of feed and permeate

\begin{tabular}{|c|c|c|c|c|}
\hline \multirow{2}{*}{ Parameter } & \multicolumn{4}{|c|}{ Value } \\
\hline & Feed with ozonation & Permeate** & Permeate with ozonation** & Standard Limits*** \\
\hline COD & $790 \mathrm{mg} / \mathrm{L}$ & $64.2 \mathrm{mg} / \mathrm{L}$ & $56.9 \mathrm{mg} / \mathrm{L}$ & $200 \mathrm{mg} / \mathrm{L}$ \\
\hline Oil and Grease & $351.61 \mathrm{mg} / \mathrm{L}$ & $8.18 \mathrm{mg} / \mathrm{L}$ & $<0.03$ & $25 \mathrm{mg} / \mathrm{L}$ \\
\hline Benzene & $<0.08 \mathrm{mg} / \mathrm{L}$ & n.a.* & n.a.* & n.a. \\
\hline Toluene & $0.10 \mathrm{mg} / \mathrm{L}$ & $0.37 \mathrm{mg} / \mathrm{L}$ & $<0.06$ & n.a. \\
\hline Xylene & 1.67 & $<0.05 \mathrm{mg} / \mathrm{L}$ & $<0.05 \mathrm{mg} / \mathrm{L}$ & n.a. \\
\hline Phenol & n.a.* & n.a.* & n.a.* & $2 \mathrm{mg} / \mathrm{L}$ \\
\hline Ammonia & n.a.* & n.a.* & n.a.* & $5 \mathrm{mg} / \mathrm{L}$ \\
\hline $\mathrm{pH}$ & n. $a^{*}$ & $\mathrm{n} . \mathrm{a}^{*}$ & n.a* & $6-9$ \\
\hline
\end{tabular}

\footnotetext{
* Permeate characteristic of the parameter was not tested because its value is below the standard limit

** Average value of PES 1 and PES 2 membrane, 1 atm

*** Standard limits based on Regulation of the Minister of State for Environment, Republic of Indonesia
} 
The removal efficiency of ozonation for xylene, toluene, and benzene reached $90 \%, 89 \%$, and $86 \%$, respectively. The removal efficiency was correlated with reaction kinetics of BTX and ozone. The reaction kinetic rates of ozone with benzene, toluene, and xylene were $4.75 \times 10^{-2}, 7.30 \times$ $10^{-2}$, and $1.82 \times 10^{-1} \mu \mathrm{g} / \mathrm{m}^{3} \cdot \mathrm{h}$, respectively.

$\mathrm{COD}$ is the oxygen required to degrade biodegradable and non-biodegradable organic compounds. As shown in Table 3, the concentration of COD was decreased by both ultrafiltration and ozone pre- or post-treatment. This finding verifies that the amount of organic compounds decreased when produced water was subjected to ultrafiltration combined with ozonation pre- or post-treatment.

\section{Conclusion}

The quality of produced water was examined based on oil and grease content as well as COD, which were found to be higher than the standard limit of wastewater for oil and gas activities. Benzene, toluene, and xylene were also detected in the produced water. Two commercial Ultrafiltration PES membranes were used to treat the produced. Ultrafiltration was modified by combining it with feed ozonation (pre-treatment) and permeate ozonation (post-treatment). This experimental work demonstrated that ultrafiltration and its combination with ozone pre-treatment and post-treatment showed effective removal of COD, oil and grease, toluene, and xylene. It is also confirmed that almost oil and grease can be removed by using this combined system. Ultrafiltration with ozone pre-treatment led to higher flux profile than ultrafiltration only. This finding verifies that ozone pre-treatment did not only remove produced water pollutants but also diminished the fouling of the ultrafiltration membrane. In addition, it was confirmed that the quality of permeate satisfied the acceptable level to discharge.

\section{References}

[1] Fakhru'l-Razi A., Pendashteh, A., Abdullah, L. C., Biak, D. R. A., Madaeni, S. S., Abidin, Z. Z. "Review of technologies for oil and gas produced water treatment", Journal of Hazardous Materials, 170 (2-3), pp. 530-551, 2009.

https://doi.org/10.1016/j.jhazmat.2009.05.044

[2] Nasiri, M., Jafari, I. "Produced Water from Oil-Gas Plants: A Short Review on Challenges and Opportunities", Periodica Polytechnica Chemical Engineering, 61(2), pp. 73-81, 2017. https://doi.org/10.3311/PPch.8786

[3] Dickhout, J. M., Moreno, J., Biesheuvel, P. M., Boels, L., Lammertink, R. G. H., de Vos, W. M. "Produced water treatment by membranes: A review from a colloidal perspective", Journal of Colloid Interface Science, 487, pp. 523-534, 2017. https://doi.org/10.1016/j.jcis.2016.10.013

$\begin{array}{ll}\text { Abbreviations } & \\ A & \text { Membrane area }\left(\mathrm{m}^{2}\right) \\ \text { BTX } & \text { Benzene, toluene, and xylene } \\ \text { BTEX } & \text { Benzene, toluene, ethylbenzene and xylene } \\ \text { COD } & \begin{array}{l}\text { Chemical oxygen demand } \\ \text { Concentration of a specific pollutant in the }\end{array} \\ & \text { feed } \\ C_{f} & \text { Concentration of specific pollutants in } \\ & \text { permeate } \\ C_{p} & \left.\text { Flux (L/ }{ }^{2} \mathrm{~h}\right) \\ J & \text { Normalization of flux profiles } \\ J / J_{0} & \text { Initial water flux } \\ J_{0} & \text { Molecular weight cut off } \\ \text { MWCO } & \text { Polyaromatic hydrocarbons } \\ \text { PAH } & \text { Polyethersulfone } \\ \text { PES } & \text { Volume (L) } \\ Q & \text { Rejection (\%) } \\ R & \text { Scanning electron microscopy } \\ \text { SEM } & \text { Time interval (h) } \\ t & \text { Transmembrane pressure (bar) } \\ \text { TMP } & \text { Total organic compound } \\ \text { TOC } & \text { Ultrafiltration } \\ \text { UF } & \text { Ultraviolet, visible spectrophotometer } \\ \text { UV-Vis } & \end{array}$

\section{Acknowledgement}

NA thanks International Conference Grant (Letter Grant Number:1361/E5.3/PB/2018) from Directorate of Research Strengthening and Development, Ministry of Research, Technology and Higher Education, The Republic of Indonesia. The authors also acknowledge Ms Henny I. Safitri, Ms Fella R. Astuti and Ms Aininu Nafiunisa for their assistance.

[4] Nielsen, M. M. Meier, S., Larsen, B. K., Andersen, O. K., Hjelle, A. "An estrogen-responsive plasma protein expression signature in Atlantic cod (Gadus morhua) revealed by SELDI-TOF MS", Ecotoxicology Environmental Safety, 74, pp. 2175-2181, 2011. https://doi.org/10.1016/j.ecoenv.2011.07.036

[5] Bakke, T., Klungsøyr, J., Sanni, S. "Environmental impacts of produced water and drilling waste discharges from the Norwegian offshore petroleum industry", Marine Environmental Research, 92, pp. 154-169, 2013.

https://doi.org/10.1016/j.marenvres.2013.09.012

[6] Munirasu, S., Haija, M. A., Banat, F. "Use of membrane technology for oil field and refinery produced water treatment-A review", Process Safety and Environmental Protection, 100, pp. 183-202, 2016. https://doi.org/10.1016/j.psep.2016.01.010 
[7] Rezakazemi, M., Maghami, M. and Mohammadi, T. "High Loaded Synthetic Hazardous Wastewater Treatment Using LabScale Submerged Ceramic Membrane Bioreactor", Periodica Polytechnica Chemical Engineering, 62(3), pp. 299-304, 2018. https://doi.org/10.3311/PPch.11459

[8] Alzahrani, S., Mohammad, A. W. "Challenges and trends in membrane technology implementation for produced water treatment: A review", Journal of Water Process Engineering, 4, pp. 107-133, 2014.

https://doi.org/10.1016/j.jwpe.2014.09.007

[9] Kulkarni, S. S., Funk, E. W., Li, N. N. "Ultrafiltration: Introduction and Definitions", In: Ho, W. S. W., Sirkar, K. K. (eds.) Membrane handbook, Van Nostrand Reinhold, New York, USA, 1992, pp. 393-387.

[10] Kumar, S., Nandi, B. K., Guria, C., Mandal, A. "Oil Removal from Produced Water by Ultrafiltration using Polysulfone Membrane", Brazilian Journal of Chemical Engineering, 34(2), pp. 583-396, 2017. https://doi.org/10.1590/0104-6632.20170342s20150500

[11] Ebrahimi, M., Ashaghi, K. S., Engel, L., Willershausen, D., Mund, P., Bolduan, P., Czermak, P. "Characterization and application of different ceramic membranes for the oil-field produced water treatment", Desalination, 245(1-3), pp. 533-540, 2009. https://doi.org/10.1016/j.desal.2009.02.017

[12] Li, Y. S., Yan, L., Bao, C., Jiang, L. "Treatment of oily wastewater by organic - inorganic composite tubular ultrafiltration (UF) membranes", Desalination, 196(1-3), pp. 76-83, 2006. https://doi.org/10.1016/j.desal.2005.11.021

[13] Salahi, A., Abbasi, M., Mohammadi, T. "Permeate flux decline during UF of oily wastewater: Experimental and modeling", Desalination, 251(1-3), pp. 153-160, 2010. https://doi.org/10.1016/j.desal.2009.08.006

[14] Wu, C., Li, A., Li, L., Zhang, L., Wang, H., Qi, X., Zhang, Q. "Treatment of oily water by a poly(vinyl alcohol) ultrafiltration membrane", Desalination, 225(1-3), pp. 312-321, 2008. https://doi.org/10.1016/j.desal.2007.07.012

[15] Duarte, C. L., Geraldo, L. L., Junior, O. A. P., Borrely, S. I., Sato, I. M., Sampa, M. H. O. "Treatment of effluents from petroleum production by electron beam irradiation", Radiation Physics and Chemistry, 71, pp. 443-447, 2004. https://doi.org/10.1016/j.radphyschem.2004.03.021

[16] Dórea, H. S., Bispo, J. R. L., Aragão, K. A. S., Cunha, B. B., Navickiene, S., Alves, J. P. H. "Analysis of BTEX, PAHs and metals in the oilfield produced water in the State of Sergipe, Brazil", Microchemical Journal, 85(2), pp. 234-238, 2007. https://doi.org/10.1016/j.microc.2006.06.002

[17] Utvik, T. I. R. "Chemical characterisation of produced water from four offshore oil production platforms in the North Sea", Chemosphere, 39(15), pp. 2593-2606, 1999. https://doi.org/10.1016/S0045-6535(99)00171-X

[18] Šilhárová, K., Derco, J., Tölgyessy, P., Valičková, M. "Reducing of organic petroleum compounds in water by ozonation / UV processes", presented at $45^{\text {th }}$ International Petroleum Conference, Bratislava, Slovak Republic, June 13, 2011.
[19] Zhu, M., Wang, H., Su, H., You, X., Jin, W. "Study on Oxidation Effect of Ozone on Petroleum-Based Pollutants in Water", Modern Applied Science, 4(1), pp. 6-11, 2010. https://doi.org/10.5539/mas.v4n1p6

[20] Ziabari, S.-S. H., Khezri, S. M., Kalantary, R. R. "Ozonation optimization and modeling for treating diesel-contaminated water", Marine Pollution Bulletin, 104(1-2), pp. 240-245, 2016. https://doi.org/10.1016/j.marpolbul.2016.01.017

[21] Zha, X.-Z., Ma, L.-M., Wu, J., Liu, Y. "The removal of organic precursors of DBPs during three advanced water treatment processes including ultrafiltration, biofiltration, and ozonation", Environmental Science Pollutant Research, 23(16), pp. 16641-16652, 2016. https://doi.org/10.1007/s11356-016-6643-Z

[22] Zhu, H., Wen, X., Huang, X. "Membrane organic fouling and the effect of pre-ozonation in microfiltration of secondary effluent organic matter", Journal of Membrane Science, 352(1-2), pp. 213-221, 2010. https://doi.org/10.1016/j.memsci.2010.02.019

[23] Kim, J.-O., Jung, J.-T., Yeom, I.-T., Aoh, G.-H. "Effect of fouling reduction by ozone backwashing in a microfiltration system with advanced new membrane material", Desalination, 202(1-3), pp. 361-368, 2007. https://doi.org/10.1016/j.desal.2005.12.075

[24] You, S.-H., Tsai, Y.-T. "Using intermittent ozonation to remove fouling of ultrafiltration membrane in effluent recovery during TFT-LCD manufacturing", Journal of the Taiwan Institute of Chemical Engineers, 41(1), pp. 98-104, 2010. https://doi.org/10.1016/j.jtice.2009.05.013

[25] You, S.-H., Tseng, D.-H., Hsu, W.-C. "Effect and mechanism of ultrafiltration membrane fouling removal by ozonation", Desalination, 202(1-3), pp. 224-230, 2007. https://doi.org/10.1016/j.desal.2005.12.058

[26] Saha, N. K., Balakrishnan, M., Ulbricht, M. "Sugarcane juice ultrafiltration: FTIR and SEM analysis of polysaccharide fouling", Journal of Membrane Science, 306(1-2), pp. 287-297, 2007. https://doi.org/10.1016/j.memsci.2007.09.006

[27] Belfer, S., Fainchtain, R., Purinson, Y., Kedem, O. "Surface characterization by FTIR-ATR spectroscopy of polyethersulfone membranes-unmodifed, modifed and protein fouled", Journal of Membrane Science, 172(1-2), pp. 113-124, 2000. https://doi.org/10.1016/S0376-7388(00)00316-1

[28] Zulaikha, S., Lau, W. J., Ismail, A. F., Jaafar, J. "Treatment of restaurant wastewater using ultrafiltration and nanofiltration membranes", Journal of Water Process Engineering, 2, pp. 58-62, 2014. https://doi.org/10.1016/j.jwpe.2014.05.001

[29] Zadorojny, C., Saxton, S., Finger, R. "Spectrophotometric Determination of Ammonia", Journal of Water Pollution Control Federation, 45(5), pp. 905-912, 1973. [online] Available at: www.jstor.org/stable/25037839 [Accessed: 3 March 2019]

[30] Ashaghi, K. S., Ebrahimi, M., Czermak, M. "Ceramic Ultra- and Nanofiltration Membranes for Oilfield Produced Water Treatment: A Mini Review", Open Environmental Sciences, 1, pp. 1-8, 2007. https://doi.org/10.2174/1876325100701010001 
[31] Maguire-Boyle, S. J., Barron, A. R. "A new functionalization strategy for oil/water separation membranes", Journal of Membrane Science, 382(1-2), pp. 107-115, 2011. https://doi.org/10.1016/j.memsci.2011.07.046

[32] Wang, C., Li, Q., Tang, H., Yan, D., Zhou, W., Xing, J. "Membrane fouling mechanism in ultrafiltration of succinic acid fermentation broth", Bioresource Technology, 116, pp. 366-371, 2012. https://doi.org/10.1016/j.biortech.2012.03.099

[33] Hua, F. L., Tsang, Y. F., Wang, Y. J., Chan, S. Y., Chua, H., Sin, S. N. "Performance study of ceramic microfiltration membrane for oily wastewater treatment", Chemical Engineering Journal, 128(2-3), pp. 169-175, 2007. https://doi.org/10.1016/j.cej.2006.10.017

[34] Yi, X. S., Yu, S. L., Shi, W. X., Sun, N., Jin, L. M., Wang, S. Zhang, B., Ma, C., Sun, L. P. "The influence of important factors on ultrafiltration of oil/water emulsion using PVDF membrane modified by nano-sized $\mathrm{TiO}_{2} / \mathrm{Al}_{2} \mathrm{O}_{3}$ ", Desalination, 281, pp. 179$184,2011$.

https://doi.org/10.1016/j.desal.2011.07.056

[35] Song, Y., Dong, B., Gao, N., Xia, S. "Huangpu River water treatment by microfiltration with ozone pretreatment", Desalination, 250(1), pp. 71-75, 2010. https://doi.org/10.1016/j.desal.2009.06.047

[36] Knudsen, B. L., Hjelsvold, M., Frost, T. K., Svarstad, M. B. E., Grini, P. G., Willumsen, C. F., Torvik, H. "Meeting the Zero Discharge Challenge for Produced Water", In: SPE International Conference on Health, Safety, and Environment in Oil and Gas Exploration and Production, Alberta, Canada, 2004, ID: SPE-86671-MS. https://doi.org/10.2118/86671-MS
[37] Carvalho, M. S., Clarisse, M. D., Lucas, E. F., Barbosa, C. C. R., Barbosa, L. C. F. "Evaluation Of The Polymeric Materials (DVB Copolymers) for Produced Water Treatment", In: at Abu Dhabi International Petroleum Exhibition and Conference, Abu Dhabi, United Arab Emirates, 2002, ID: SPE-78585-MS. https://doi.org/10.2118/78585-MS

[38] Jiménez, S., Micó, M. M., Arnaldos, M., Medina, F., Contreras, S. "State of the art of produced water treatment", Chemosphere, 192, pp. 186-208, 2018. https://doi.org/10.1016/j.chemosphere.2017.10.139

[39] Santos, M. R. G., Goulart, M. O. F., Tonholo, J., Zanta, C. L. P. S. "The application of electrochemical technology to the remediation of oily wastewater", Chemosphere, 64(3), pp. 393-399, 2008. https://doi.org/10.1016/j.chemosphere.2005.12.036

[40] Freire, D. D., Cammarota, M. C., Santanna, G. L. "Biological Treatment of Oil Field Wastewater in a Sequencing Batch Reactor", Environmental Technology, 22(10), pp. 1125-1135, 2001. https://doi.org/10.1080/09593332208618203

[41] Sun, Y., Zhang, Y., Quan, X. "Treatment of petroleum refinery wastewater by microwave-assisted catalytic wet air oxidation under low temperature and low pressure", Separation and Purification Technology, 62(3), pp. 565-570, 2008. https://doi.org/10.1016/j.seppur.2008.02.027

[42] Li, Q., Kang, C., Zhang, C. "Waste water produced from an oilfield and continuous treatment with an oil-degrading bacterium", Process Biochemical, 40(2), pp. 873-877, 2005. https://doi.org/10.1016/j.procbio.2004.02.011 